JOSÉ CRISTÓBAL AGUÍRRE LOBATO

\title{
O EXERCÍCIO ABUSIVO DO PODER FAMILIAR E OS LIMITES DA INTERVENÇÃO JUDICIAL NA FAMÍLIA
}

Mestrado

Universidade de São Paulo

Faculdade de Direito

São Paulo, 2013 
JOSÉ CRISTÓBAL AGUÍRRE LOBATO

\section{O EXERCÍCIO ABUSIVO DO PODER FAMILIAR E OS LIMITES DA INTERVENÇÃO JUDICIAL NA FAMÍLIA}

Dissertação apresentada à Comissão Julgadora da
Faculdade de Direito da Universidade de São
Paulo, como exigência parcial para obtenção do
título de Mestre em Direito Civil, sob a
orientação da Professora Titular Doutora Giselda
Maria Fernandes Novaes Hironaka.

Universidade de São Paulo

Faculdade de Direito

São Paulo, 2013 


\section{BANCA EXAMINADORA:}

Orientadora: Giselda Maria Fernandes Novaes Hironaka

Segundo (a) Examinador (a)

Terceiro (a) Examinador (a) 
"Licet sapere sine pompa, sine invidia."

(Sêneca) 
Para José Lourenço (in memoriam) e Maria Cecília: meus pais. 


\section{Agradecimentos:}

Todos já dependemos da generosidade de várias pessoas em diversas ocasiões. No entanto, tenho que agradecer nominalmente:

À Professora Giselda Maria Fernandes Novaes Hironaka, por sua generosidade e por vivenciar o princípio da afetividade, na prática.

Ao Professor Euclides de Oliveira, cuja iniciativa possibilitou tudo isto.

Ao Professor Paulo Lôbo, por sua gentileza em prontamente esclarecer questão mal compreendida.

Ao amigo Luis Fernando Franchini que, sempre bem informado, suscitou o tema da participação societária do menor.

Por fim, agradeço especialmente à Maria Helena Martins, pelo incentivo ao longo dos anos; à Maria Stela de Andrade, pela ajuda providencial com a revisão gramatical; à Beatriz Silvério Fernandes, por me escutar verdadeiramente. 


\section{SUMÁRIO}

\section{INTRODUÇÃO (p.01)}

\section{CAPÍTULO I. PODER FAMILIAR}

1.1. Relações familiares - ontem e hoje (p.04)

1.2. Pátrio poder, poder familiar e autoridade parental (p.13)

1.3. Natureza jurídica do poder familiar (p.25)

1.4. Sujeitos do poder familiar (p.28)

1.5. Conteúdo do poder familiar ( $p .33)$

\section{CAPÍTULO II. ABUSO DO DIREITO}

2.1. Noção introdutória: abuso do direito, mecanismo voltado para o concreto (p.42)

2.2. Antecedentes históricos (p.52)

2.2.1. Direito Romano (p.52)

2.2.2. Direito Francês (p.58)

2.2.3. Direito Luso Brasileiro (p.67)

2.2.4. Código Bevilaqua (p.72)

2.2.5. Civil Português de 1966 (p.74)

2.3. O Código Civil Brasileiro de 2002 (p.75)

2.3.1. O atual momento da civilística brasileira e o resgate dos valores (p.76)

2.3.2. A diferença específica entre ato ilícito e abuso do direito ( $p .77)$

2.4. Inflexões do artigo 187 nas relações familiares (p.80)

\section{CAPÍTULO III. INTERVENÇÃO JUDICIAL NA FAMÍLIA - DIMENSÃO PATRIMONIAL}

3.1. Patrimônio familiar (p.86)

3.2. Usufruto e administração dos bens dos filhos (p.94)

3.3. Proteção dos bens dos filhos (p.110)

3.4. Participação societária da criança e do adolescente (p.122)

3.5. Obrigação alimentar em evolução (p.126) 


\section{CAPÍTULO IV. INTERVENÇÃO JUDICIAL NA FAMÍLIA - DIMENSÃo EXISTENCIAL}

4.1. Afetividade, solidariedade e cuidado (p.135)

4.2. Intervenção estatal na família (p.141)

4.3. O juiz de família e a interdisciplinaridade (p.146)

4.4. Indícios de abuso do poder familiar (p.151)

4.5. Situações de intervenção judicial (p.156)

4.6. Poder geral de cautela e melhor interesse da criança e do adolescente (p.164)

4.7. Limites interventivos (p.168)

CONCLUSÃO (p.173)

REFERÊNCIAS (p.177)

$\operatorname{ANEXOS}(p .195)$ 


\section{RESUMO}

A família sofreu, no século passado, - séc. XX - diversas mudanças. As próprias relações mudaram: industrialização e urbanização aceleradas, emancipação da mulher, duas Guerras Mundiais que alavancaram o tema dos direitos humanos, com evidente repercussão nos direitos da personalidade. Tudo isso alterou o perfil da família e das relações que ocorrem em seu seio.

$\mathrm{Na}$ verdade, estabeleceu-se uma perspectiva limitadora do poder em geral, da ascendência sobre outrem, inclusive no âmbito do pátrio poder, hoje poder familiar.

Sem embargo disso, passada a euforia inicial, é hora de buscar caminhos para a plena efetivação desses direitos. Isso dependerá, em grande medida, da própria interpretação judicial, já que na decisão jurisdicional o ordenamento convertido numa fórmula específica para a solução daquela lide atinge o seu ápice. Se a afetividade e a grita por justiça e ética nas relações familiares é inafastável, mais do que isso, é louvável, porque consagra a dignidade da pessoa humana, por outro lado, a ideologia e a patrulha moral em temas existenciais devem ser evitadas. Ativismo judicial não se confunde com invasividade. A intrujice do Estado na família pela função legislativa, executiva ou judiciária deve incentivar um repensar das próprias expectativas que os operadores do Direito, sobretudo do Direito de Família, possuem a respeito do potencial transformativo de seus saberes.

Assim, sempre buscando o justo termo, a dissertação examina as hipóteses de intervenção judicial no exercício abusivo do poder familiar, tanto na dimensão patrimonial quanto na dimensão existencial. Na primeira, analisa-se a administração dos bens dos filhos, o usufruto que, por lei, lhe é correlato e sua interpretação à luz do princípio do melhor interesse da criança e do adolescente. Na segunda, o objeto da investigação é o ponto ótimo de equilíbrio entre a intervenção que concretiza os direitos e a intervenção invasiva, errônea. Surgem ponderações sobre a ideologia e sua influência na exegese judicial, em temas como alienação parental e abandono afetivo que habitam o novo léxico deste Direito de Família sequioso de substância o qual, entretanto, não pode abdicar de uma postura autocrítica sob pena de manietar as próprias possibilidades de realização pessoal que alega defender.

PALAVRAS-CHAVE: Pátrio poder - poder familiar - intervenção judicial administração de bens do filho - usufruto legal - alienação parental - abandono afetivo provas e indícios. 


\begin{abstract}
Family underwent several changes in the last century, the twentieth century. The very relationships did change: accelerated (rapid) industrialization and urbanization, women's emancipation, two World Wars, levered the human rights subject, with obvious repercussion on the rights of personality. All of that has modified family profile and the relationships that occur within its core.
\end{abstract}

Actually, in general, a limiting perspective of power was established on the ascendancy over the other, inclusively in the extent of parental power, currently said family, or parental authority.

With no embargo of this, after leaving behind the initial euphoria, now is the moment to look for ways towards the thorough accomplishment of these rights. This will depend, largely, on the judicial interpretation, for in the jurisdictional decision converted into a specific formula aimed at the solution of that dispute, it reaches its climax. If, on one hand, affectivity and the outcry for justice and ethics within family relationships cannot be set apart, and, more than that, they are praiseworthy - for they consecrate dignity of the individual - on the other hand, when it comes to existential matters, ideology and moral patrolling ought to be avoided. Judicial activism does not confound with invasiveness. State intrusion on family through legislative, or executive, or judiciary activity, should encourage a review of the very expectations that Law operating professionals have - particularly those in the Family Law field - regarding the transformational potential of their knowledge.

Therefore, looking always for the right boundary, the dissertation investigates the hypotheses for judicial intervening in abusive family authority, considering not only property dimension, but also the existential. On the first we analyze the administration of assets of sons, the usufruct that by force of law correlates to it, and its interpretation in the light of best interest for child and adolescent. On the second, the object of our investigation is the optimal balance point between intervention that makes rights concrete, and the invasive, erroneous interference. We ponder over ideology and its influence on the judicial exegesis, in subjects such as parental alienation and affective abandonment, which dwell in this Family Law new lexicon, avid for substance, but which, however, cannot waive from a self-criticism posture, under penalty of handcuffing the very own possibilities of personal fulfillment it alleges to defend.

KEYWORDS : Parental power - family authority - judicial intervention - administration of son's properties - lawful usufruct - parental alienation - affective abandonment - proofs and circumstantial evidences. 